\title{
圧電素子による沸騰現象からのエナジーハーベスティングに関する実験研究*
}

\author{
山田 昇 $^{* 1}$, 加藤 洋平 ${ }^{* 2}$
}

\section{Experimental Study of Energy Harvesting from Boiling Phenomenon with Piezoelectric Devices}

\author{
Noboru YAMADA ${ }^{* 1}$ and Yohei KATO \\ ${ }^{* 1}$ Dept. of Mechanical Engineering, Nagaoka University of Technology \\ Kamitomiokamachi 1603-1, Nagaoka-shi, Niigata, 940-2188 Japan
}

Energy harvesting is a process of extracting small amount of energy from ambient environment. Currently, electricity of $\mu \mathrm{W}$ range is enough to drive small electronic devices such as wireless sensors and networking devices. This study reports experimental result of a unique boiling energy harvester (BEH) which gains power from kinetic energy of boiling bubbles by means of piezoelectric devices. To verify working principle and characteristic, fundamental experiment has been conducted by a visible BEH with two types of piezoelectric materials (PVDF and PZT). As a result, BEH successfully generated electricity from boiling phenomenon and maximum power of $9.2 \mu \mathrm{W}$ was obtained when using PZT. Vibration characteristic was analyzed to determine optimal electric load to BEH. In addition, effect of boiling heat transfer area and cavity height on the performance was also examined toward further improvement. Finally, it was shown that BEH coupled with energy harvesting circuit demonstrated practical power generation.

Key Words : Energy Harvesting, Boiling, Piezo-Element, Energy Conversion, Energy Saving, Vibration

\section{1. 緒言}

近年，無線センサネットワークの普及やマイコンなどの低消費電力化によりエナジーハーベスティング (Energy harvesting) と呼ばれる発電技術が注目されている. エナジーハーベスティングとは, 熱や振動, 光, 電磁波など身の回りに存在するエネルギーを比較的微小な電力に変換する技術であり，環境発電とも呼ばれてい る(1)(2). $1 \mu \mathrm{W}$ 数 $\mathrm{W}$ 程度の発電量があればセンサで測定したデータを間欠的に無線送信することが可能であり(3), 多用なアプリケーションへの普及が期待されている．エナジーハーベスティングと無線センサ技術を組み合わせ ることにより電池と配線が不要になり，電池使用量削減，メンテナンス性の向上，配線重量軽減，配線コス卜低 減，設計上の自由度増大などの様々なメリットが考えられる。

一方, 工業分野においては, 各種発電プラントのボイラ, 空調冷凍機器の蒸発器, ヒートパイプ, 各種のキャ ビテーション現象，より身近な例では，湯沸かし器，やかんなど，沸騰現象が支配メカニズムとなって機能して いるデバイスが多く存在する。これらにおいて沸騰気泡のエネルギーから微小電力を回収し, 機器の状態管理・ 監視・通報などに用いることができれば有益であると考えられる，沸騰気泡からの発電について，Xu らは，圧電 体膜で囲まれた閉空間内の作動流体の相変化を利用したマイク口熱機関を提案している(4). また, Lee らは MEMS センサ等への利用を目的として単一蒸気泡サイズを検知する圧電体カンチレバーの変位量に関する力学モデリン グと実験検証を行い(5)，さらに本研究で対象と寸る圧電素子を用いた沸騰気泡のエナジーハーベスティングの概 念を特許出願している( ${ }^{(6)}$ しかしながら，本概念に関する具体的な実験研究報告は著者等の調査範囲においては 見当たらない.

そこで本研究では，沸騰現象からのエナジーハーベスティングに適する新たなデバイスの開発を目的として，

* 原稿受付 2013 年 3 月 12 日

*1 正員, 長岡技術科学大学（广940-2188 新潟県長岡市上富岡町 1603-1）

*2 長岡技術科学大学大学院機械創造工学専攻

E-mail: noboru@nagaokaut.ac.jp 
圧電素子を用いて沸騰気泡の運動エネルギーからの発電を試みた結果について報告する．従来技術のゼーベック 素子では素子自体に温度差を与える必要があるが，本手法では素子自体に温度差を与える必要は無く，沸騰気泡 の運動から圧電変換を介して電力を得ながら, 周波数等の発電特性から沸騰現象のモニタリングが同時に行える 優位性がある．なお，圧電素子を用いた流体の非定常運動（風や海流など）からのエネジーハーベスティング手 法については多くの報告がなされている例え゙(7)(8). 本研究ではまず, 水を作動流体とする小型実験装置を構築し, 原理確認を行い, 振動周波数を考慮した最適負荷, 沸騰伝熱面積の影響, 沸騰容器の厚さの影響, 素子の種類お よび取り付け形態による影響等を調査した。ささらに, 蓄電要素を含む典型的なエナジーハーベスティング回路と 組み合わせることにより LED 発光が可能であることを実証した.

\section{2. 沸騰エナジーハーベスターの動作原理}

図 1 に沸騰現象から微小電力回収を行う沸騰エナジーハーベスター (Boiling energy harvester, 以下 BEH)

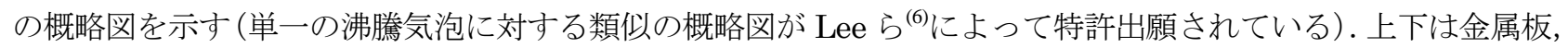
側面は断熱壁で構成された密閉容器があり。中には動作温度に適する沸点を有する作動流体が封入されている. 作動流体中には圧電素子が取り付けてある. 下面の高温熱源によって中の作動流体が加熱され, 沸騰気泡が発生 する. 発生した沸騰気泡が圧電素子に衝突し, 素子が振動することにより発電する. 沸騰気泡は冷却面で凝縮し, 液体となり, 浮力の作用により加熱面へ戻る. 本概略図はゼーベック素子のように上下面に温度差を与えること で発電が行える形態の例であるが，原理的にはボイラ等の沸騰伝熱面近傍に圧電素子を組み込むなどの多用な派 生形態が考えられる. 本研究では, 比較的簡便な条件でのフィージビリティを調查するため, 本概略図に近い形 態での実験検証を行った.

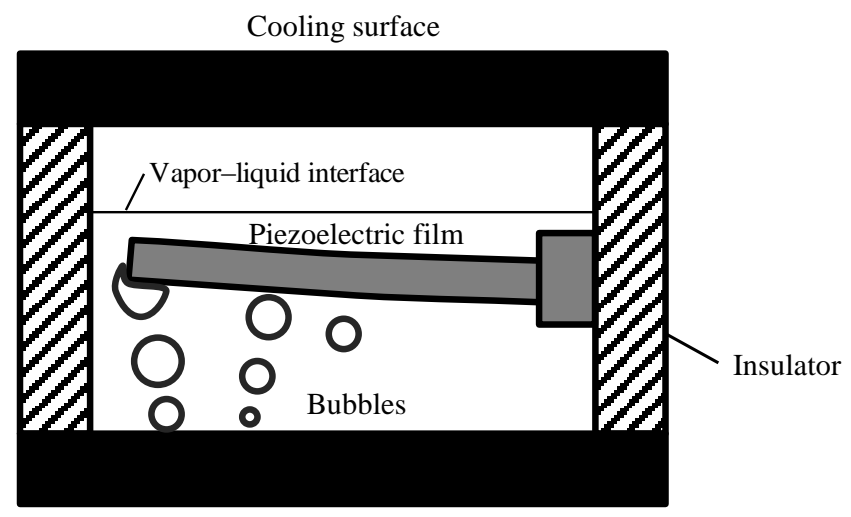

Heating surface

Fig.1 Concept of energy harvesting device from boiling bubbles

\section{3. 実験装置および実験方法}

図 2 に BEH の模式図を, 図 3 に製作した BEH の写真を示す. BEH は透明なポリカーボネートと 2 枚の厚さ $1 \mathrm{~mm}$ の銅板で作られた密閉容器と圧電素子により基本構成される. 外形が一辺 $70 \mathrm{~mm}$, 高さ $30 \mathrm{~mm}$ の直方体に $50 \mathrm{~mm} \times 50 \mathrm{~mm}$ の内部空間が設けてあり，中には一枚の圧電素子 $(42 \mathrm{~mm} \times 16 \mathrm{~mm})$ が容器内半分の高さに一端 を固定端, 多端を自由端にして取り付けてある. 図 4 および表 1 に実験で使用した圧電素子の仕様を示す. 圧電 素子にはポリマー系材料で比較的柔らかな PVDF（ポリフッ化ビニリデン）を用いた. また，容器を透明にする ことにより, 外から圧電素子の様子を観察できるようにした. 圧電素子の出力は, 素子からリード線を取り出し, 負荷抵抗を介して最小測定電圧 $2.5 \mu \mathrm{V}$ （測定誤差 $0.1 \%$ ）のデータロガーにより，10 $\mathrm{msec}$ サンプリングで計測し た. 図 5 に示すように, 外部負荷抵抗 $R_{0}$ を変化させ, 測定部抵抗 $R_{\mathrm{m}}=100 \mathrm{k} \Omega$ を固定值とし, その両端の電圧を 計測した. BEH 下面には高温熱源としてカートリッジヒーターを熱伝導グリスで密着し, 電圧調整器で出力を 変化させて加熱した. 




Fig.2 Schematic diagram of experimental apparatus of BEH

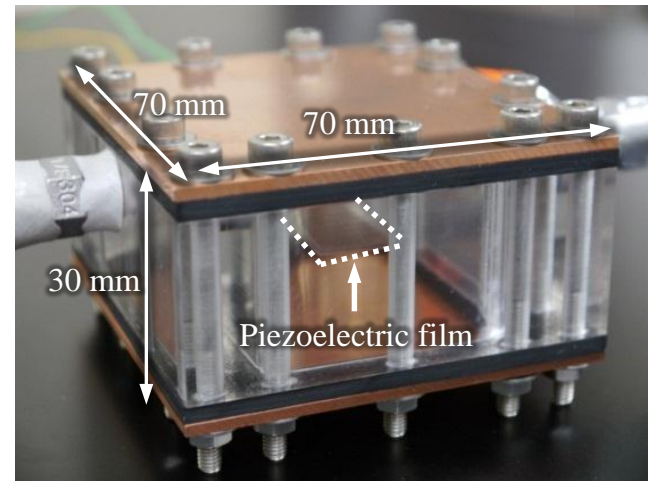

Fig.3 Photograph of BEH

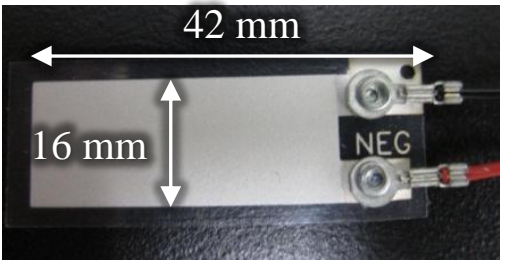

Fig.4 Photograph of PVDF as piezoelectric film

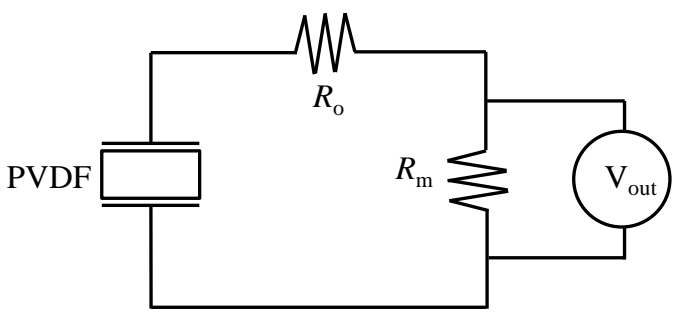

Fig.5 Measurement circuit

Table 1 Specification of PVDF

\begin{tabular}{ll}
\hline Parameter & Value \\
\hline Material & Polyvinylidene fluoride: PVDF \\
Relative permittivity: $\varepsilon / \varepsilon_{0}$ & 12 \\
Capacitance: $C$ & $1.38 \mathrm{nF}$ \\
Thickness: $t$ & $0.205 \mathrm{~mm}$ \\
Width and length & $16 \mathrm{~mm} \times 42 \mathrm{~mm}$ \\
Dielectric loss factor: $\tan \delta$ & 0.25 \\
\hline
\end{tabular}


$\mathrm{BEH}$ 上面には低温熱源としてヒートシンクを設置し，一定温度の冷水をポンプ循環して冷却を行い， BEH の 上下面に温度差を与えられるようにした，加熱·泠却面温度 $T_{\mathrm{H}}$ および $T_{\mathrm{C}}$ をそれぞれ $\mathrm{T}$ 型熱電対で計測した. 作 動流体には水を用い, 大気圧下で圧電素子のある高さ位置まで水を満たした後, 必要に応じて BEH 内を真空ポ ンプで減圧し，圧力計を見ながら作動流体の沸点を調節した。冷却水の温度および循環流量は $20^{\circ} \mathrm{Cおよび} 4.0$ liter/min で常に一定とし, ヒーターの出力 $Q_{\mathrm{H}}$ を変化させながら, 実験を行った. すべての実験において実験中 の容器内部の圧力変化は， $Q_{\mathrm{H}}=70 \mathrm{~W}$ では $5 \pm 0.5 \mathrm{kPa}, Q_{\mathrm{H}}=160 \mathrm{~W}$ では $10 \pm 0.5 \mathrm{kPa}$ であった．なお，作動流体に 水を選択した理由は, 水は潜熱が大きいため気泡膨張の度合いが大きく, 素子に衝突する可能性が高く, 素子に よる運動エネルギーの回収量が大きくなると予想したためである.

\section{4. 実験結果}

\section{$4 \cdot 1$ 原理確認実験}

まず， BEH で発電が可能であるかを検証した．ヒーター出力 $Q_{\mathrm{H}} を 70 \sim 160 \mathrm{~W}\left(2.8 \sim 6.4 \mathrm{~W} / \mathrm{cm}^{2}\right)$ の間で変化 させて発電性能を調べた。 この実験では外部負荷抵抗 $R_{0}=1 \mathrm{M} \Omega$ を接続して圧電素子の出力を測定し, 計 3 回の 平均值を得た. 結果として, ヒーター出力 $Q_{\mathrm{H}}=70 \sim 160 \mathrm{~W}$ の範囲すべてにおいて容器内で沸騰が生じ, 圧電素 子から出力を得ることができた. 図 6 は出力電圧 $V_{\text {out }}$ と加熱·冷却面温度の時間変化であり, 図 $6(\mathrm{a})$ は $Q_{\mathrm{H}}=70 \mathrm{~W}$, 図 6(b)は $Q_{\mathrm{H}}=160 \mathrm{~W}$ の結果である. どちらも安定した沸騰がおこり, 発生した沸騰気泡との衝突により圧電素子 が変形・振動する様子を確認できた. ヒーター出力によって沸騰の状態は変化し, 压電素子の出力にも変化が見 られた，ヒーターが低出力の場合は，発生する気泡が少なくなり，圧電素子が小さな振幅しか得ることができず 出力電圧が低下した。 一方, ヒーター出力が大きくなるにつれて発生気泡数が増加し, 圧電素子が大きな振幅を 得て出力電圧が増加した. また, 気泡数が増えると水面の摇れも大きくなり圧電素子の変形に寄与しているよう に見受けられた. ヒーター出力が大きくなるにしたがい加熱面と冷却面の温度差も大きくなった. 水の飽和温度 と伝熱面温度の差である過熱度を測定すると， $Q_{\mathrm{H}}=160 \mathrm{~W}$ 時には $16 \mathrm{~K}$ であり，核沸騰領域に相当した.

図 7 は, 各ヒーター出力において定常状態 $60 \mathrm{~s}$ 間の発電電力 $P$ を比較したものである. ここでは, 加熱面と冷 却面の温度差の時間変化量が $60 \mathrm{~s}$ あたり $1 \%$ 以内になった時を定常状態とした. 発電電力 $P$ は, 定常状態の平均 出力電圧 $V_{\mathrm{ave}}$ と測定部抵抗 $R_{\mathrm{m}}=100 \mathrm{k} \Omega$ から回路の電流 $I$ を求め, オームの法則より求めた.

$$
P=I^{2} R_{a}
$$

ここで， $R_{\mathrm{a}}$ は回路全体の抵抗であり,$R_{a}=R_{0}+R_{\mathrm{m}}$ である. ヒーター出力が高いほど発電電力も高 $<, Q_{\mathrm{H}}=$ $160 \mathrm{~W}$ 時に最大 $0.062 \mathrm{\mu W}$ であった. 以上より, BEH により沸騰現象から微小電力を回収できることを確認でき た. しかし, 得られた電力はエナジーハーベスティングとしても小さく, さらに出力を向上させる必要がある.

\section{$4 \cdot 2$ 圧電素子の最適負荷}

発電出力向上のためには，圧電素子に最適負荷をかける必要がある．圧電素子による振動発電には，振動周波 数によって決まる最適負荷 $R_{\mathrm{opt}}$ が存在し，式(2)により近似的に算出することができる(9).

$$
R_{\text {opt }}=\left|R_{s}+\frac{1}{j \omega C}\right|
$$

ここで, $R_{\mathrm{s}}$ は素子の内部抵抗， $\omega$ は角周波数，Cは静電容量である. また, $\omega=2 \pi f, R_{\mathrm{s}}=\tan \delta / 2 \pi f C$ で表され, $\tan \delta$ は誘電損失, $f$ は振動周波数である. 式(2)より, 最適負荷を求めるためには振動周波数を知る必要がある. そこで, 前述の実験により得られた電圧の時間変化特性からフーリエ変換により振動周波数を解析した. 図 8 は 図 6(b)に示した $Q_{\mathrm{H}}=160 \mathrm{~W}$ 時の電圧変動に対してフーリエ変換を行った結果である. 黒線がフーリエ変換した元 の結果であり，赤線は移動平均を示している，これより，素子の振動は $20 \mathrm{~Hz}$ 前後の成分が卓越していることが 


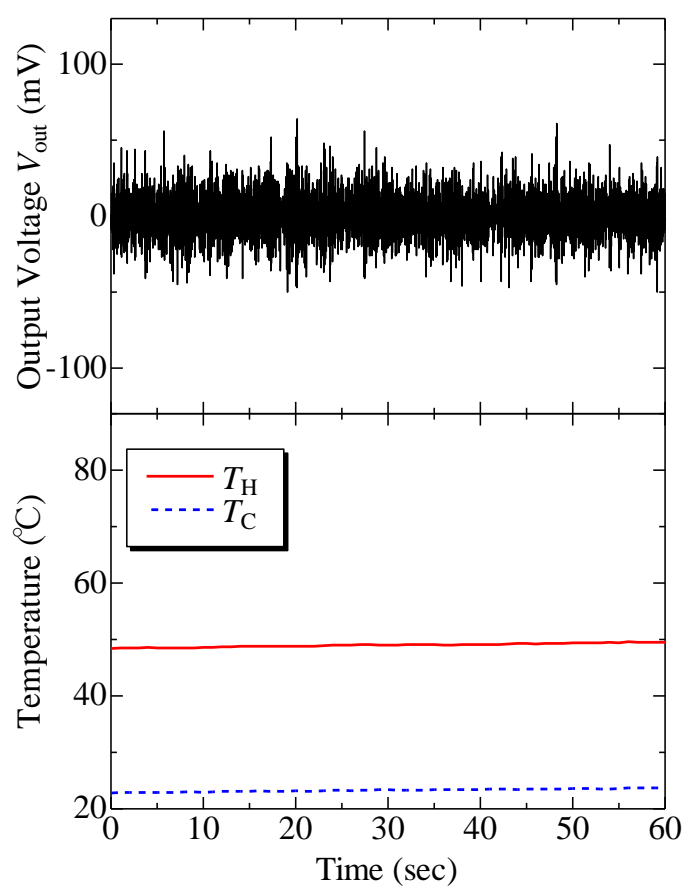

(a) $Q_{\mathrm{H}}=70 \mathrm{~W}$



(b) $Q_{\mathrm{H}}=160 \mathrm{~W}$

Fig.6 Time-variation of hot and cold side temperature and output voltage



Fig.7 Experimental result: heater power vs. output power

わかる. $f=20 \mathrm{~Hz}$ と仮定して計算を行うと, 最適負荷として $R_{\mathrm{opt}}=4.6 \mathrm{M} \Omega$ が得られる. また, ある振動周波数に 対する最適負荷時の理論電圧 $V_{\mathrm{opt}}$ を式(3)により求めることができる.

$$
V_{o p t}=V_{O C}\left|\frac{R_{o p t}}{R_{o p t}+\frac{1}{j \omega C}+R_{s}}\right|
$$

ここで, $V_{\mathrm{oc}}$ は開放電圧であり, 実測により決定できる. 理論電圧 $V_{\mathrm{opt}}$ から理論出力 $P_{\mathrm{th}}=V_{\mathrm{opt}}^{2} / R_{\mathrm{o}}$ を求めると, $Q_{\mathrm{H}}=160 \mathrm{~W}$ 時の振動周波数帯である $f=15 \sim 25 \mathrm{~Hz}$ では, $3 \sim 6 \mathrm{M} \Omega$ の負荷抵抗で出力のピークが得られるであろう ことがわかる．前述の実験で使用した負荷抵抗は $1 \mathrm{M} \Omega$ であったため，最適負荷に変更することで $1.7 \sim 2.5$ 倍の 発電電力が得られると予想される. そこで負荷抵抗を $1 \mathrm{M} \Omega$ から $5 \mathrm{M} \Omega$ に変更して比較実験を行った. 図 9 に負 荷抵抗を $1 \mathrm{M} \Omega$ および $5 \mathrm{M} \Omega$ とした際のヒーター出力 $Q_{\mathrm{H}}$ と発電電力 $P$ との関係を示す. 結果として, $5 \mathrm{M} \Omega$ 時の 出力は $1 \mathrm{M} \Omega$ 時より 1.7 倍向上し, 理論出力の傾向とほぼ一致した. また, この時の最大出力は $0.12 \mu \mathrm{W}$ であっ 


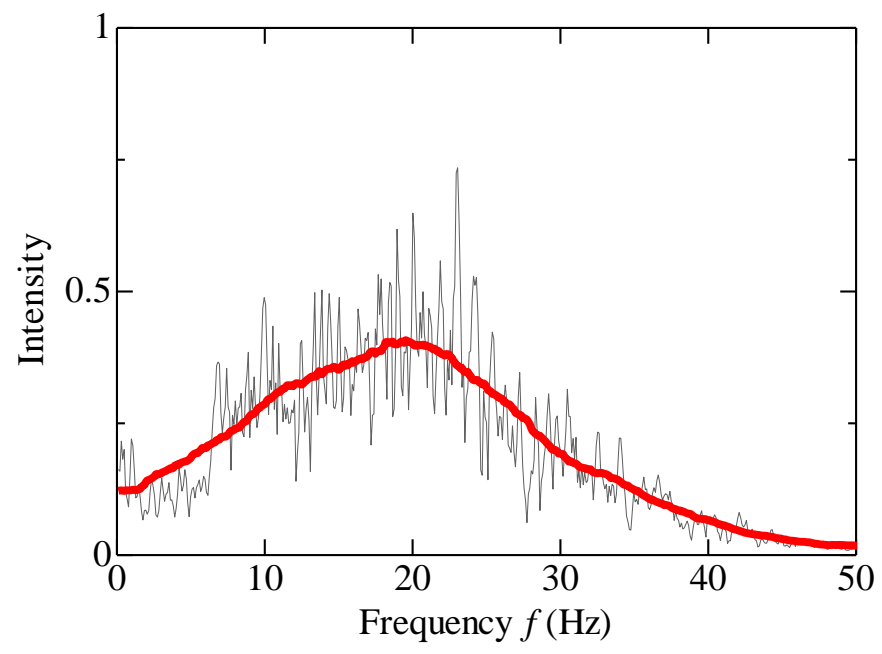

Fig.8 Result of Fourier transform analysis for $Q_{\mathrm{H}}=160 \mathrm{~W}$ (red line: moving average)

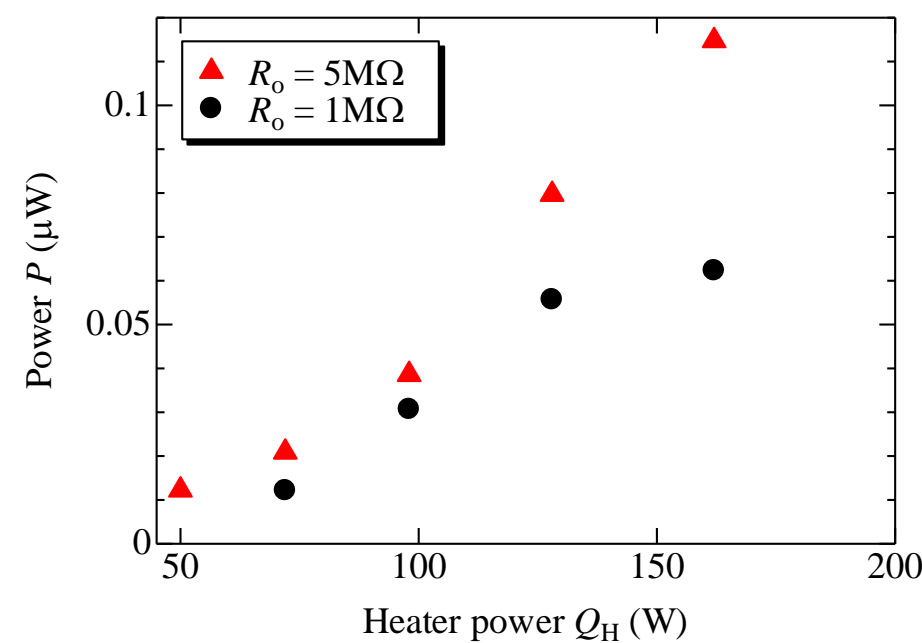

Fig.9 Experimental result: output power vs. heater power for two different resistances

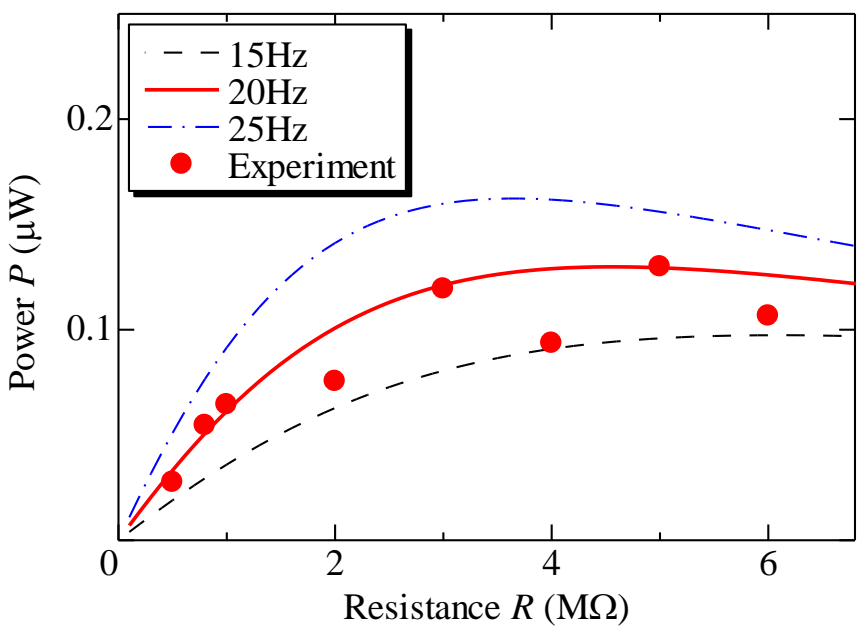

Fig.10 Comparison between experimental output power and theoretical output power for different frequency 
た. 図 10 には， $Q_{\mathrm{H}}=160 \mathrm{~W}$ 時の各負荷抵抗における発電電力の実験值と理論值を比較した結果を示す. 実際の 発電電力は $15 \mathrm{~Hz}$ と $20 \mathrm{~Hz}$ に対する理論出力の間に分布しており, 素子が実際に受けた振動は $15 \sim 20 \mathrm{~Hz}$ の周波 数範囲にあったことが推定できる.

以上より，振動周波数に応じた最適負荷を接続することで発電電力を向上できることを確認し，BEH におい ても最適負荷が重要である点を示すことができた．しかし，ここで得られた $0.12 \mu \mathrm{W}$ は依然として小さく，さら なる出力向上が必要である. そのためには, 沸騰現象と振動発電との関係をさらに詳しく調べる必要がある.

\section{$4 \cdot 3$ 沸騰伝熱面積の影響}

現象の理解をさらに深めるため, 伝熱面において沸騰気泡が発生する面積を変化させ, 気泡発生領域の面積が 発電におよぼす影響を調べた。

図 11 に前述の実験に用いてきた伝熱面と，気泡発生領域（沸騰伝熱面積）を抑制した伝熱面を示す．図 11(a) は $50 \mathrm{~mm}$ 角の $\mathrm{Cu}$ 製の市販平板である. 伝熱面に特段の表面加工はされておらず，沸騰時には不特定多数の点か ら気泡が発生する. 図 $11(\mathrm{~b})$ は同じ $\mathrm{Cu}$ 製平板において中心部の $10 \mathrm{~mm}$ 角の領域のみ $\mathrm{Cu}$ 面を露出させ，それ以 外は熱伝導率の低いポリマー系テープ材で覆った改造伝熱面である.これにより $\mathrm{Cu}$ 露出領域からのみ気泡を発 生させることができた.これらの伝熱面を用いて比較実験を行った.

図 12 にヒーター出力 $Q_{\mathrm{H}}$ と圧電素子の発電電力 $P$ を示寸. また, 表 2 に各 $Q_{\mathrm{H}}$ における加熱面温度を示寸. 負 荷抵抗は $50 \mathrm{~mm}$ 角の伝熱面で最大出力が得られた $5 \mathrm{M} \Omega$ とした. 同条件での実験を 3 回行い, 平均值をプロット した. $10 \mathrm{~mm}$ 角の伝熱面による電力は $Q_{\mathrm{H}}=160 \mathrm{~W}$ 時に $0.07 \mu \mathrm{W}$ であり, $50 \mathrm{~mm}$ 角で得られた $0.12 \mu \mathrm{W}$ より 低

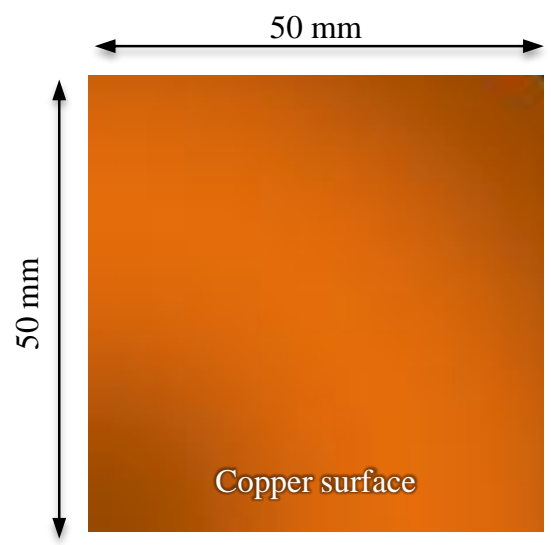

(a) $50 \mathrm{~mm} \times 50 \mathrm{~mm}$

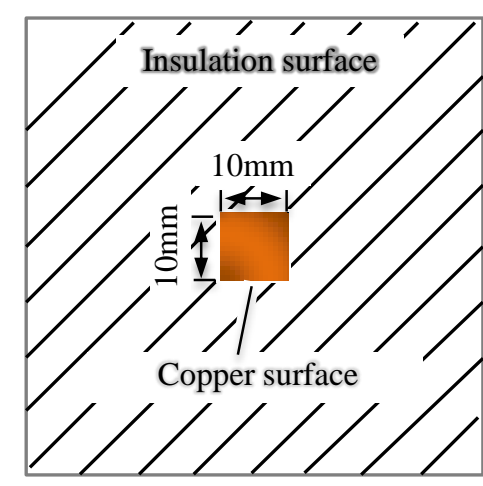

(b) $10 \mathrm{~mm} \times 10 \mathrm{~mm}$

Fig.11 Boiling heat transfer area for comparison

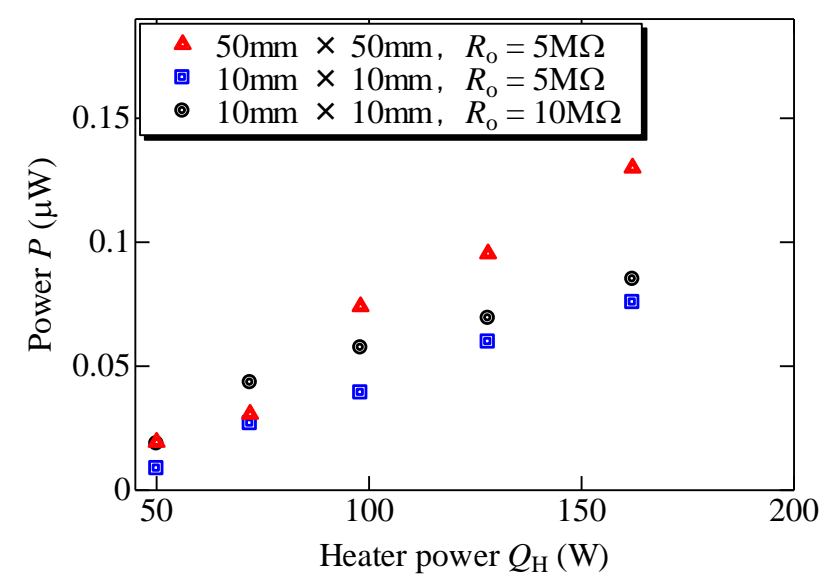

Fig.12 Experimental result: output power vs. heater power for two different boiling heat transfer area
Table 2 Hot side temperature corresponds to Fig.12.

\begin{tabular}{lrrrrr}
\hline$Q_{\mathrm{H}}[\mathrm{W}]$ & 50 & 70 & 100 & 130 & 160 \\
\hline$T_{\mathrm{H}}\left[{ }^{\circ} \mathrm{C}\right]$ & & & & & \\
$\quad$ (a) $50 \times 50 \mathrm{~mm}$ & 40.5 & 48.5 & 59.4 & 68.4 & 81.7 \\
$\quad$ (b) $10 \times 10 \mathrm{~mm}$ & 48.3 & 55.1 & 62.6 & 71.6 & 81.4 \\
\hline
\end{tabular}




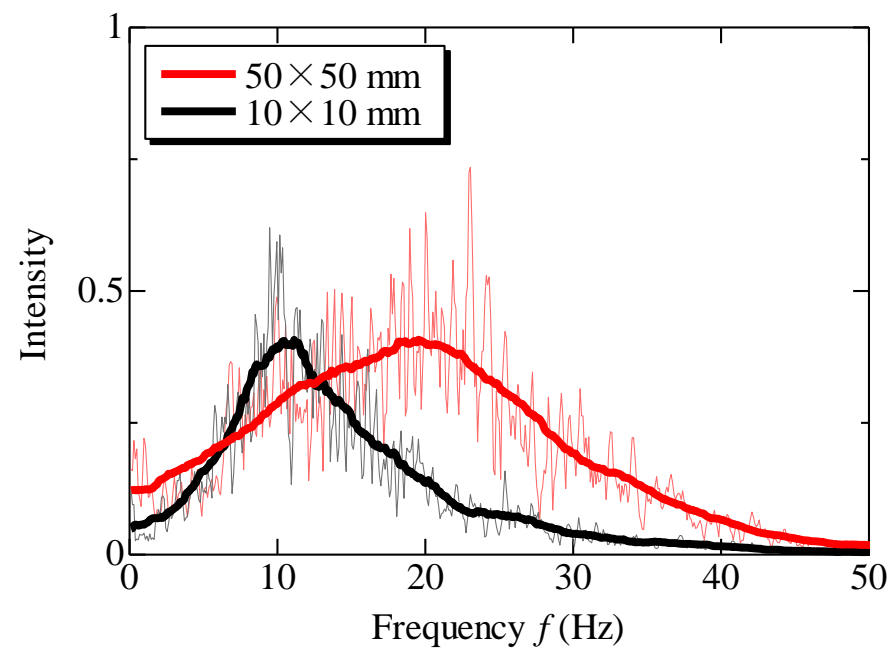

Fig.13 Result of Fourier transform for $Q_{\mathrm{H}}=160 \mathrm{~W}$ corresponding to Fig.12 (solid lines: moving average)

下した. 次に, 出力電圧の時間変化からフーリエ変換により振動周波数を解析した. 図 13 は $Q_{\mathrm{H}}=160 \mathrm{~W}$ 時の出 力に対する両伝熱面での振動周波数特性である. $50 \mathrm{~mm}$ 角では $20 \mathrm{~Hz}$ 前後の振動成分が卓越しているのに対して, $10 \mathrm{~mm}$ 角では $10 \mathrm{~Hz}$ 前後にピークを持つことが分かる. 気泡発生領域が大きくなると個々の気泡の離脱周期が重 ね合わされ，高周波成分が増え，結果的に出力が増えたことが予想される．ここで試みに $10 \mathrm{~Hz}$ に対する理論最 適負荷である $10 \mathrm{M} \Omega$ に負荷抵抗を変えて実験を行ったところ, $Q_{\mathrm{H}}=160 \mathrm{~W}$ 時での電力は $0.085 \mu \mathrm{W}$ に増加したが, $50 \mathrm{~mm}$ 角の伝熱面での結果よりも低い值であった. 圧電素子は広い周波数範囲に対する負荷の最適化が困難であ るため, 理想的には 1 気泡につき 1 枚の圧電素子を独立に配置し, 発生気泡の離脱周期に対して最適化すれば発 電電力を一層高められる可能性がある。このように沸騰現象の状態が発電におよぼす影響は大きく, 沸騰気泡の 発生状況に応じて最適な素子の取付形態があると考えられる.

そこで, 圧電素子の取付形態が発電におよぼす影響を調べるため, 図 14 に示すようにサイズの異なる圧電素 子を用いて実験を行った. Case 1 と Case 2 は両者の総面積が等しくなるように, Case 1 の場合は素子 1 枚を単独 で, Case2 の場合は 2 枚を独立に容器内に設置し, 図 11(a)の伝熱面で実験を行った. 結果を図 15 に示す. Case 1 の発電電力は $Q_{\mathrm{H}}=160 \mathrm{~W}$ 時に $0.18 \mu \mathrm{W}$, Case 2 は $0.25 \mu \mathrm{W}$ であり, 素子総面積が同じでも 2 枚独立に設置した方 が 1 枚単独にくらべて 1.4 倍大きな電力が得られた. また, Case 2 では同じ素子を 2 枚にしたことによって, Case 3 とくらべて約 2 倍の電力を得ることができたが, Case 1 では面積が 2 倍になっても Case 3 の約 1.3 倍の電力しか 得られなかった. そこで, 本実験についても出力電圧からフーリエ変換により振動周波数の解析を行ったところ,

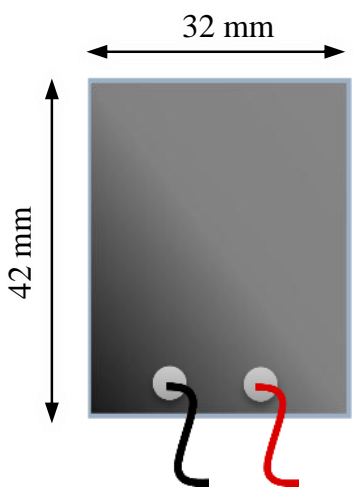

(b) Case 1



(a) Case 2

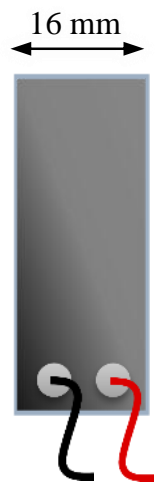

(c) Case 3

Fig.14 Configurations of PVDF film for comparison 


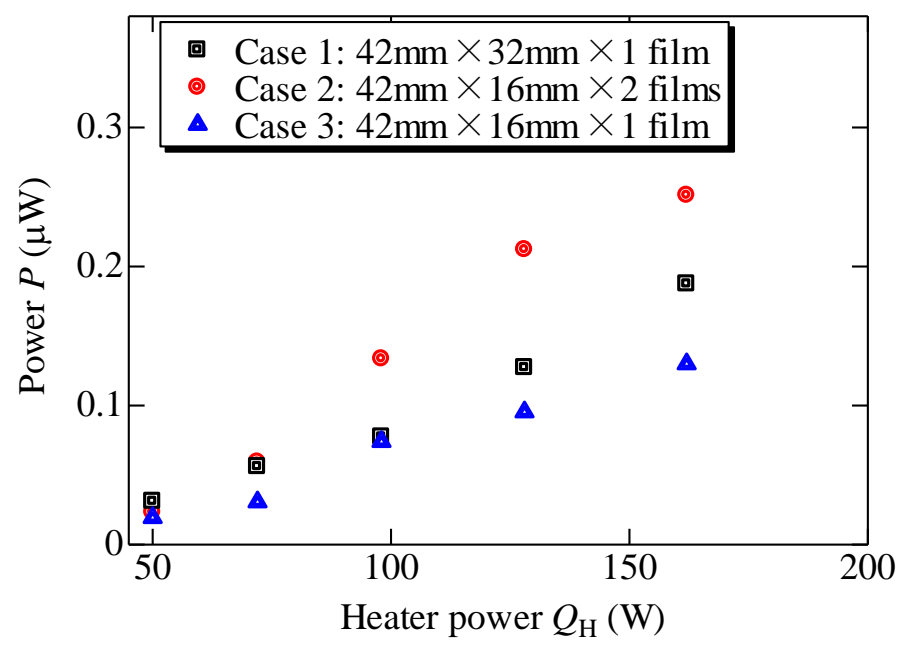

Fig.15 Comparison of output power between different film size and numbers of piezoelectric film

Case 2 は 1 枚の時と同じく $20 \mathrm{~Hz}$ 前後に卓越した周波数成分を得られたのに対し, Case 1 では $15 \mathrm{~Hz}$ 前後に振動 のピークがシフトしており，振動周波数が低下した，そのため，出力が Case2 にくらべて低下したと思われる. このことは，面積の大きな素子では広い周波数範囲に対応できないことを示唆しているものと考えられ，先の考 察と矛盾しない.

以上の結果から, 沸騰気泡の運動エネルギーを圧電素子で効果的に電力に変換するためには, 1 枚の大きな素 子よりも複数枚の小さな素子を用いた方が有効であると言える.

\section{4 -4 セラミックス圧電素子による発電性能}

以上の実験では，比較的に弾性のあるPVDFを用いてきた。これは，弾性があることでより多く沸騰気泡の運 動エネルギーを回収できるであろうと予想したためだが，発電出力は小さい結果となった，そこで，素子の種類 による発電性能への影響を調べるため, PVDFよりも固いセラミックス系圧電素子（PZT : チタン酸ジルコン酸

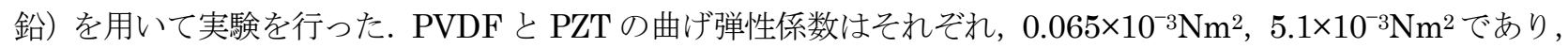
值の大きいPZT が硬い素子であることを示す.

図 16 に実験に用いた PZT の写真, 表 3 に仕様を示す. PZT はPVDFよりも変形しにくいが, 圧電体として はPVDF よりも高い誘電率を有する．今回使用した素子は，中央の金属板（シム）の両側に PZT を貼りあわせ たバイモルフ型素子である。これを PVDF の場合と同様に容器中央に取付け，図 11(a)の伝熱面でヒーター出力

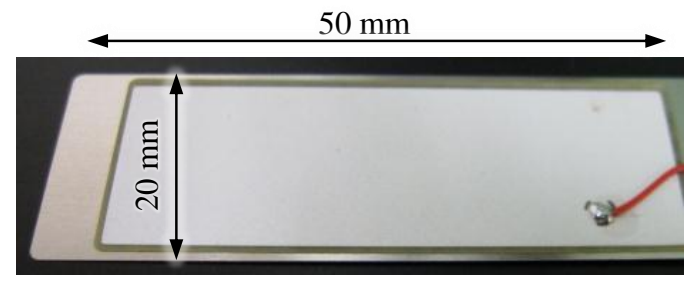

Fig.16 Photograph of PZT as piezoelectric film

Table 3 Specification of PZT

\begin{tabular}{ll}
\hline Parameter & Value \\
\hline Material & Lead zirconate titanate: PZT \\
Relative permittivity: $\varepsilon / \varepsilon_{0}$ & 4000 \\
Capacitance: $C$ & $100 \mathrm{nF}$ \\
Thickness: $t$ & $0.4 \mathrm{~mm}$ \\
Width and length & $20 \mathrm{~mm} \times 50 \mathrm{~mm}$ \\
Dielectric loss factor: $\tan \delta$ & 0.01 \\
\hline
\end{tabular}






Fig.17 Experimental result with PZT: output power vs. resistance

$Q_{\mathrm{H}}$ を変化させて出力測定を行った. 負荷抵抗についても同様に, 測定部抵抗 $R_{\mathrm{m}}=10 \mathrm{k} \Omega$ とし, 外部抵抗 $R_{0}$ を変 化させ，全体の負荷抵抗 $R_{a}$ に対寸る評価を行った.

図 17 に $Q_{\mathrm{H}}=160 \mathrm{~W}$ 時に得られた各負荷抵抗における発電電力を示寸. 最大発電電力は $R_{\mathrm{a}}=20 \mathrm{k} \Omega$ 時の $9.2 \mu \mathrm{W}$ であり, PVDF で得られた $0.12 \mu \mathrm{W}$ より約 70 倍高い值が得られた．また，その他の負荷抵抗では発電電力が相 対的に減少し, PVDF と同様に最適負荷が存在した. PZT はPVDF に比べて固く変形しにくいにも関わらず, 高い発電性能を示したことから，BEH の発電性能は素子の材料特性にも大きく影響され，沸騰状態に応じた最 適な材料特性が存在すると考えられる. 以上のように本実験で得られた電力はエナジーハーベスティングとして 利用することが可能なレベルとなった.

\section{$4 \cdot 5$ 沸騰容器厚さの影響}

さらに BEH の特性を把握するため, 密閉容器の厚さが発電性能へ及ぼす影響を調べた. BEH の容器厚さを $30 \mathrm{~mm}$ から $10 \mathrm{~mm}$ になるように，ポリカーボネートの高さを薄く変更して発電実験を行った. 実験には高出力 が得られた PZT を用い，これまでと同様に容器半分の高さに素子を取付けた．なお，4.1 節において水面の摇れ による影響の可能性について述べたが，水位を変えた実験により，その影響は素子と伝熱面積との距離による影 響にくらべ無視できることを確認した. ヒーター出力 $Q_{\mathrm{H}}=160 \mathrm{~W}$ 時に負荷抵抗 $R_{\mathrm{a}}$ を変化させて発電電力を測定

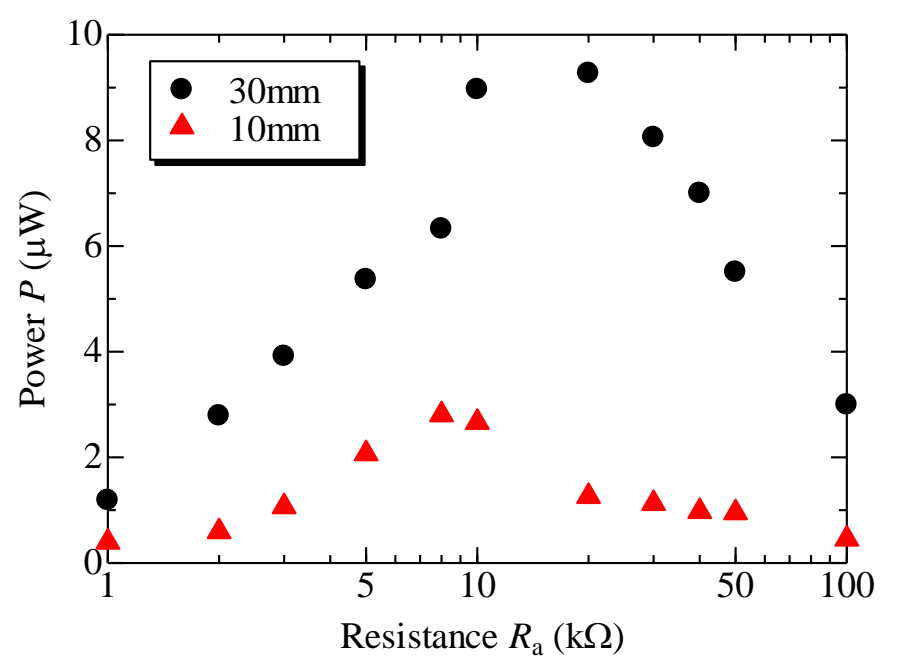

Fig.18 Output power vs. resistance for two different BEH cavity thickness 
した結果を厚さ $30 \mathrm{~mm}$ 時の結果と一緒に図 18 に示す. 厚さ $10 \mathrm{~mm}$ では $R_{\mathrm{a}}=8 \mathrm{k} \Omega$ 時に最大 $2.85 \mu \mathrm{W}$ の発電電力 を得られたが，これは，厚さ $30 \mathrm{~mm}$ における最大值 $9.2 \mu \mathrm{W}$ の約 $1 / 3$ である.これより $\mathrm{BEH}$ の容器厚さが薄く なると発電性能が低下寸ることが確認された。

熊谷らは極小間隙の沸騰熱伝達に関して報告を行っており(10)(11)，その中で狭い隙間内の沸騰では合体気泡が発 生し，隙間内を占める気泡の割合が高くなると報告している．本実験でも合体気泡に近い様子が見られた． BEH 内部に合体気泡が生じ，合体気泡が素子を覆うような形で存在した場合，沸騰気泡（気液界面）が素子と干渉す る割合が下がり，気泡から受け取る振動エネルギーが減少する可能性がある．このため発電電力が低下したので はないかと考えられる，また，核沸騰領域での沸騰では間隙が狭くなるにつれて，同じ伝熱面過熱度に対する伝 熱面からの熱流束は，隙間が十分広い場合より大きくなり，極大熱流束は小さくなると報告されている．本実験 においても, 加熱・冷却面温度差の低下（熱流束増加）が見られたが，同時に温度が大きく変動する不安定性も確 認された。このように BEH にとって容器厚さは重要な要素であることがわかった.

\section{$4 \cdot 6$ エナジーハーベスティング回路による LED 発光}

最後に BEH の電源としての有効性を検証するために LED 発光実験を行った. BEH による発電電力は変動が 大きいため, 実際に発電電力を利用する際には, 整流·蓄電を行い, 一定間隔で電気を利用する方法が適している (12)(13). 図 19 に製作したエナジーハーベスティング回路の基本構成を示寸. 圧電素子からの出力は全波整流器で


チによって切り離されており, エネルギーが一定レベルまで蓄えられた後にスイッチを ONにし, 負荷に電力を 供給することができる. 本実験では負荷として赤色 LED と定電流用の負荷抵抗を接続した. 圧電素子には PZT を用いた．実験の際には，蓄電用コンデンサ $C_{\text {charge }}$ の両端電圧をエレクトロメータでモニタリングし，一定の電 圧レベルに達したときにスイッチを ON L，LED を発光させた． C charge には $10 \mu \mathrm{pF}$ の積層セラミックスコンデン

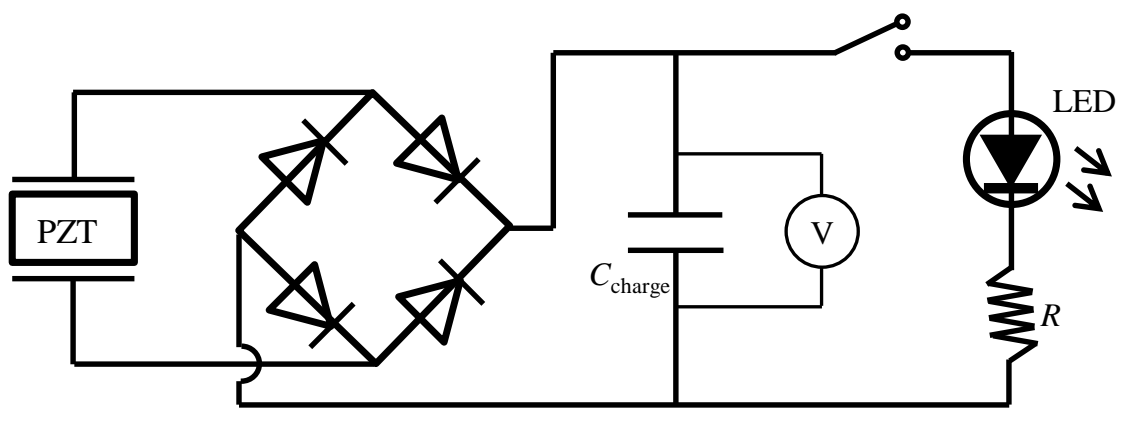

Fig.19 Energy harvesting circuit used in the present experiment

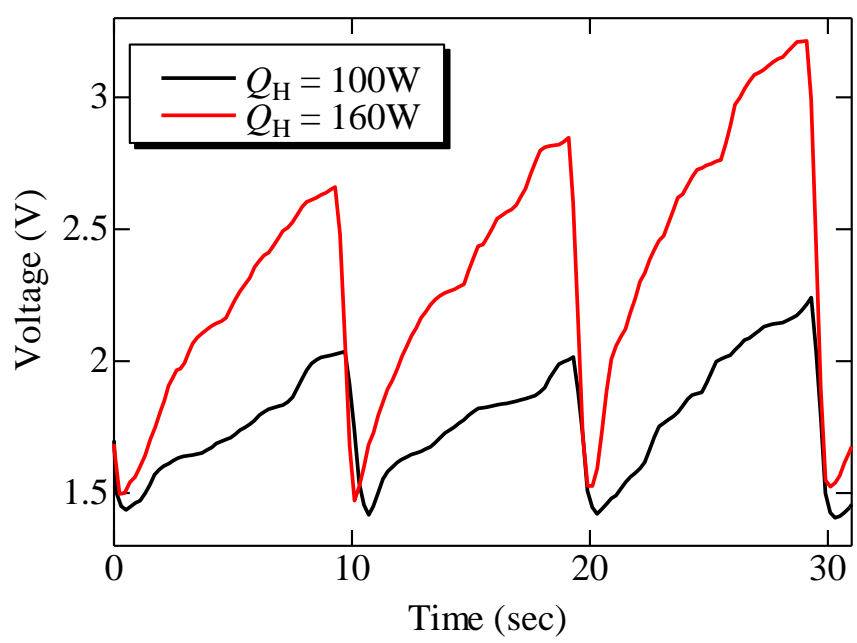

Fig.20 Time variation of charging voltage at $C_{\text {charge }}=10 \mu \mathrm{F}$ 


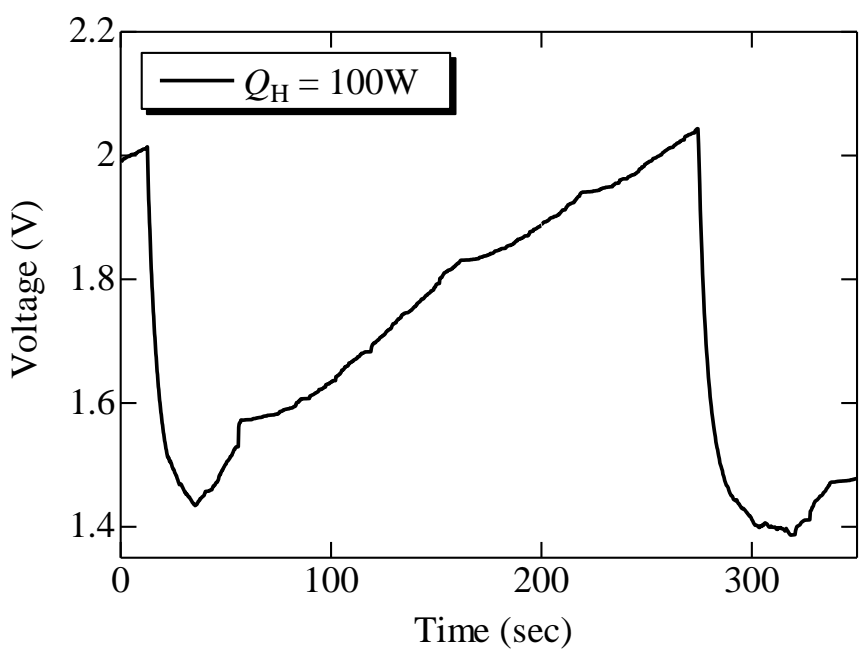

Fig. 21 Time variation of charging voltage at $C_{\text {charge }}=330 \mu \mathrm{F}$

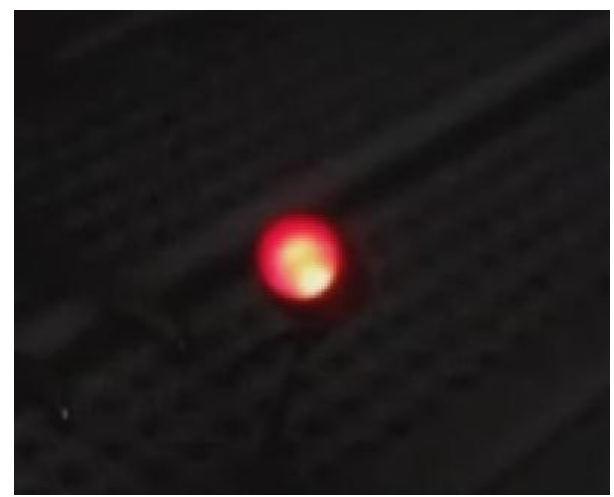

Fig.22 LED emission obtained by BEH with energy harvesting circuit

サを， $R$ には $10 \mathrm{k} \Omega$ の負荷抵抗を接続した.

図 20 に蓄電電圧の測定結果を示す.蓄電電圧が $2 \mathrm{~V}$ を超えたときにスイッチを ON寸るとLEDを発光できた. $Q_{\mathrm{H}}=100 \mathrm{~W}$ 時には LED を発光させると蓄電電圧が $2 \mathrm{~V}$ から約 $1.5 \mathrm{~V}$ まで低下し, 消灯する. この時に消費された エネルギーは $Q=1 / 2 C_{\text {charge }} V^{2}$ の関係から $14.4 \mu \mathrm{J}$ と見積もられる。一旦消灯してから再び $2 \mathrm{~V}$ まで昇圧するの に要する時間は約 $10 \mathrm{~s}$ であることから発電量は $1.44 \mathrm{\mu W}$ であることがわかる. また，ヒーター出力を $160 \mathrm{~W} に$ 増 加させると, 同じ $10 \mathrm{~s}$ における電圧上昇が増え, エネルギーは最大 $40.0 \mu \mathrm{J}$ 蓄えられた. この時の発電量は $4.0 \mu \mathrm{W}$ であり, ヒーター出力に応じて発電量が増加したことがわかる.

さらに，コンデンサ容量を増加することで，蓄えられるエネルギーが増加し，長時間 LED を発光させること ができた. 図 21 はコンデンサを $C_{\mathrm{charge}}=330 \mu \mathrm{F}$ に変更したときの蓄電電圧の測定結果である. 約 $2 \mathrm{~V}$ まで昇圧 寸るのに $10 \mu \mathrm{F}$ の時に比べて 24 倍の時間を要したが，240s 間で $330 \mu \mathrm{J}$ のエネルギーを蓄えることができ，約 20s の間 LED を発光させることができた. LED 発光様子を図 22 に示す.このように, 用途に応じてコンデン サ容量などを変化させることで，多くのアプリケーションへの適用が可能となる．以上のように，実際に BEH の発電電力により LED を発光させることができ, 電源としての有効性を確認することができた.

\section{5. 結言}

本研究では, 沸騰現象から微小電力を回収する新たなデバイスとして圧電素子を用いた沸騰エナジーハーベス ター（BEH）を試作し，基礎的な実験を行うことにより以下の知見を得た. 
（1） 圧電素子を用いて沸騰現象から発電することが可能であり, 熱源の出力が高くなるほど発電電力が増加す ることを確認した．また，試作実験装置において圧電素子が沸騰気泡から得た振動周波数は $20 \mathrm{~Hz}$ 前後で あり，振動発電の理論式に基づく最適負荷を接続することで出力の向上を確認した.

（2）ポリマー系圧電素子（PVDF）よりもセラミックス系圧電素子（PZT）を用いた場合の方が BEH の発電 性能は高くなり，サイズ $20 \mathrm{~mm} \times 50 \mathrm{~mm}$ の $\mathrm{PZT}$ では $50 \mathrm{~mm} \times 50 \mathrm{~mm}$ の沸騰伝熱面積から最大 $9.2 \mu \mathrm{W}$ の 発電出力が得られ, 圧電素子の種類による影響を確認した.

（3）沸騰伝熱面積および素子の取り付け状態を変えた実験結果より, 沸騰気泡の運動エネルギーを圧電素子で 電力変換する場合には，1枚の大きな素子よりも複数枚の小さな素子を用いた方が有効である可能性が示 唆された. また，BEH の沸騰容器厚さを薄くした場合には合体気泡の影響により出力が低下寸ることを 確認した.

（4）整流・蓄電を含むエナジーハーベスティング回路と組み合わせることで LED を発光させることができ, $\mathrm{BEH}$ が微小電力アプリケーションの電源として使用可能であることを示した.

以上のように, 本研究では比較的簡便な条件でのフィージビリティを調査したが, 今後はデバイス姿勢の影響, 凝縮液挙動の影響, 圧電素子一の衝突前後における気泡運動ルートの影響, 各種の実際的な沸騰伝熱面への適用 などについて詳細に検討を進める必要がある。

\section{文献}

(1) 鈴木雄二, “マイクロ環境発電デバイスの研究動向”，電気学会誌，Vol. 128, No. 7 (2008), pp. 435-438.

(2) Galchev, T., Kim, H., and Najafi, K., "Micro Power Generator for Harvesting Low-Frequency an Nonperiodic Vibrations", Journal of Microelectromechanical Systems, Vol. 20, No. 4 (2011), pp. 852-866.

(3) Ottman, G., Hofmann, H., Bhatt, A., and Lesieutre, G., "Adaptive Piezoelectric Energy Harvesting Circuit for Wireless Remote Power Supply”, IEEE Transactions on Power Electronics, Vol. 17, No. 5 (2002), pp. 669-676.

(4) Xu, C., Hall, J., Richards, C., Bahr., D, and Richards, R., "Design of a Micro Heat Engine", Proceedings of IMECE-MEMS, Vol. 2 (2000), pp. 261-267.

(5) Lee, H. J., Changa, Y. S., Lee, Y. P., Jeong, K-H., and Kim, H-Y., "Deflection of Microcantilever by Growing Vapor Bubble", Sensors and Actuators A: Physical, Vol.136, Issue 2 (2007), pp.717-722.

(6) Lee, Y. P., "Microelectromechanical generator using bubbles", U.S.Patent 0160543 A1, 2003-8-28.

(7) Wang, D. A., and Ko, H. H., "Piezoelectric energy harvesting from flow-induced vibration", Journal of Micromechanics and Microengineering, Vol.20, No.2 (2010), 025019.

（8）宮城潤平, 陸田秀実, 土井康明, 田中義和, “弾性圧電デバイスを用いた風力エネルギー利用に関する研究”, 日本 機会学会論文集 B 編, Vol.78, No.789 (2012), pp.1068-1072.

(9) Kim, H., Pariya, S., and Uchino, K., "Modeling of Piezoelectric Energy Harvesting Using Cymbal Transducers", Japanese Journal of Applied Physics, Vol. 45, No. 7 (2006), pp.5836-5840.

(10) 熊谷哲, 海野絋治, 武山斌郎, “沸騰と凝縮をともなう極小間げきの熱伝達 (第 1 報, 周囲温度が自由である場合)”, 日本機械学会論文集 B 編，Vol. 45, No. 399 (1979), pp. 1723-1731.

(11) 熊谷哲, 海野紿治, 武山斌郎, “沸騰と凝縮をともなう極小間げきの熱伝達 (第 2 報, 周囲温度を一定に保つ場合)”, 日本機械学会論文集 B 編，Vol. 45, No. 399 (1979), pp. 1732-1739.

(12) 松本光一, 猿渡久美雄, 鈴木雄二, “エレクトレット環境振動発電器を用いた電池レス無線センサの試作”, 電気学 会論文誌 C（電子・情報・システム部門誌），Vol. 132, No. 3 (2012), pp. 344-349.

(13) Kong, N., Sam, D., Erturk, A., and Inman, D. J., "Resistive Impedance Matching Circuit for Piezoelectric Energy Harvesting", Journal of Intelligent Material Systems and Structures, Vol. 21 (2010), pp.1293-1302. 